\title{
A Game-Based Health Program for Improving Functional Health and Social Engagement in Long-Term Care Residents
}

\author{
ID K. Jason Crandall ${ }^{1}$ ID Jean Neils-Strunjas ${ }^{2}$
}

\begin{abstract}
After entering long-term care (LTC), many residents experience continued declines in functional status, activities of daily living (ADLs), and increased fall risk. Therefore, there is a significant need for activities capable of improving/maintaining functional status, decreasing social isolation, and increasing residents' quality of life. Bingocize ${ }^{\circledR}$, a strategic combination of exercise, education, and the game of bingo, is an innovative program shown to fulfill this need. The purpose of this article is to describe an on-going United States (U.S.) Center for Medicare and Medicaid Civil Money Penalty (CMP) grant-funded project to implement Bingocize ${ }^{\circledR}$ in multiple LTC facilities. As part of this project, local universities and their faculty and students from across the state help LTC staff administer the program. Over 800 trained LTC staff and students, and most importantly, over 1300 residents have successfully participated so far. Bingocize ${ }^{\circledR}$ can be a positive addition to LTC activities because the program helps improve/maintain functional status and social engagement. Applying for CMP funding either individually, or in partnership with a local university, is a pragmatic way for LTC facilities to access and sustain Bingocize ${ }^{\circledR}$ and other evidence-based programs.

Keywords: Exercise, quality of life, range of motion, intergenerational, Center for Medicare and Medicaid, therapy, physical activity, social engagement

\section{Key Practitioners Message}

$>$ A lack of social engagement and physical activity are major contributors to the continued decline in functional status and quality of life of LTC residents.

$>$ Bingocize ${ }^{\circledR}$, a strategic combination of exercise, education, and the game of bingo, is an innovative program shown to improve quality of life.

> A U.S. Center for Medicare and Medicaid Civil Money Penalty grant is a pragmatic way to access Bingocize ${ }^{\circledR}$ and is also available for other projects or programs capable of improving nursing home residents' quality of life.
\end{abstract}

\section{Problem - Significance}

A lack of social engagement and physical activity are major contributors to residents' continued decline in functional status, activities of daily living (ADLs), and increased fall risk in long-term care (LTC) residents (Dipietro, Campbell, Buchner, et al., 2019). Therefore, there is a significant need for easy-to-use and enjoyable activities capable of improving/maintaining functional status, decreasing social isolation, and increasing residents' quality of life. Bingocize ${ }^{\circledR}$, a combination of exercise, education, and the game of bingo, is an innovative health promotion program that addresses these needs (Crandall, Fairman, \& Anderson, 2015).

Correspondence: K. Jason Crandall. 2413 Nashville Road Ste. 12342101 Bowling Green - United States. e-mail: jason.crandall@ wku.edu

Author: ${ }^{1}$ Center for Applied Science in Health and Aging, Western Kentucky University

${ }^{2}$ Department of Communication Sciences and Disorders, Western Kentucky University 


\section{Innovation}

Bingocize ${ }^{\circledR}$ is an innovative and strategic combination of physical exercise and the game of bingo. The program consists of two 45-60-minute sessions each week. A session begins with a group of LTC residents sitting at tables with individual bingo cards in an area large enough to accommodate the residents. Trained LTC staff members, often with help from trained university students, serve as program leaders. University students positively affect $L T C$ residents' quality of life, and the students, in turn, are positively impacted. Students report being more empathetic to the needs of LTC residents with increased interest in aging-related careers (Neils-Strunjas, Crandall, Shackelford, et al., 2018). See university students leading a Bingocize ${ }^{\circledR}$ session for long-term care residents in Figure 1. All participants provided permission for the use of video and still photography. of movement followed by calls of bingo is continued until a participant wins the bingo game. After the first game is completed, additional games of bingo allow for completion of the exercises and to keep the residents' interest in the game. The program exercises improve components of functional mobility such as endurance, strength, and balance (Dipietro et al., 2019). There is a special emphasis on ensuring residents complete at least 15 minutes of active range of motion exercises to help satisfy the U.S. Center for Medicare and Medicaid (CMS) requirements. The strength exercises closely resemble functional exercises that can improve ADLs and functional status as well as reduce fall risk. For example, therapy balls are used to increase grip strength which can lead to an improvement in the daily activity of dressing. In fact, restorative therapists may successfully integrate residents' therapy into Bingocize ${ }^{\circledR}$ sessions because the exercises are adaptable for a wide

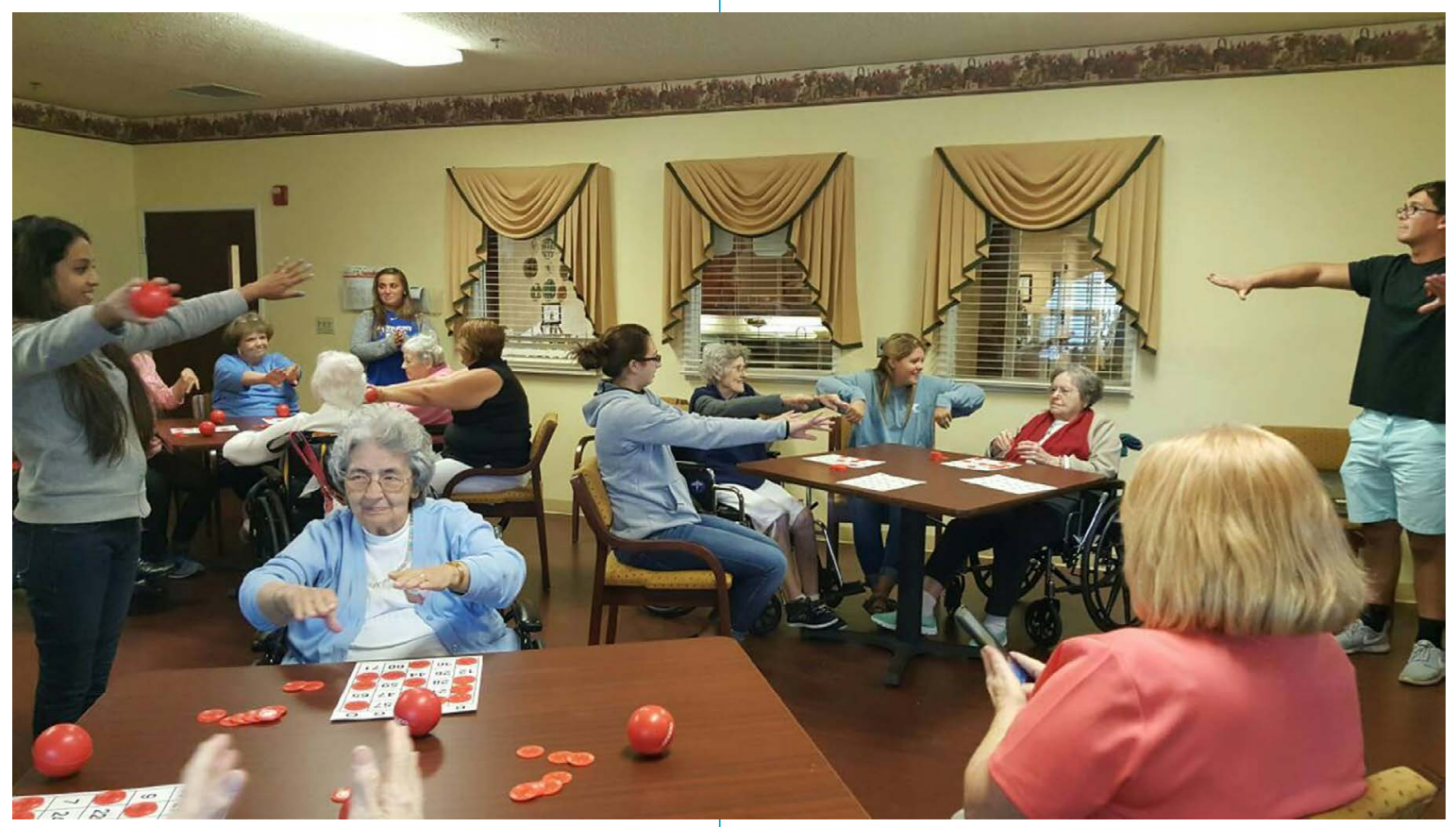

Figure 1: University students leading long-term care residents in a Bingocize ${ }^{\circledR}$ session. *

The residents complete a series of gentle physical exercises followed by the program leader calling a bingo letter/number combination. This pattern

\footnotetext{
* The authors obtained permission from the students and residents to take this photo and use for this manuscript.
}

range of residents' physical and cognitive abilities.

Bingocize ${ }^{\circledR}$ is recognized by the U.S. Administration on Community Living and National Council on Aging as an evidence-based program. Multiple investigations, funded by the Kentucky 
Science and Engineering Foundation, the Retirement Research Foundation, and the National Institutes of Health, confirmed the positive effects of Bingocize ${ }^{\circledR}$ on older adults. In one investigation, a group of older adults attended over $80 \%$ of the sessions, and significantly improved muscular strength, flexibility, balance, and cardiorespiratory fitness over 10 weeks (Crandall et al., 2015). In a second investigation, older adults significantly improved on 7 of 8 functional performance measures when compared to a waitlisted control group. Just as crucial, the adherence rate was $97 \%$, and over $86 \%$ of participants were retained in the experimental group (Crandall \& Steenbergen, 2015). In a recent investigation, participants improved functional performance, health knowledge, gait parameters, patient activation, and aspects of cognition (Shake et al., 2018, Falls et al., 2018; Dispennette et al., 2019).

The effects of the program on social engagement in older adults suffering from dementia at a memory care facility were also examined. Bingocize ${ }^{\circledR}$ provided a focused activity that tapped into the remote memory of bingo games combined with the encouragement to follow movements demonstrated and prompted by university student leaders. Residents displayed more nonverbal (i.e., following commands, gestures directed towards others) and task-related verbal behavior during Bingocize ${ }^{\circledR}$ than during other activities (coloring, listening to music, eating a snack, etc.) (French et al., 2016). Residents were also found to talk with others and report being happy during Bingocize ${ }^{\circledR}$ (Stevens, 2019).

\section{Implementation}

Recognizing the potential for Bingocize ${ }^{\circledR}$ to create a culture change within LTCs, our research team was awarded Kentucky Civil Money Penalty (CMP) funding with the primary goal of training LTC staff to lead Bingocize ${ }^{\circledR}$ in 28 LTC facilities across the state. The CMP funding mechanism is available to nursing homes and other organizations to help improve nursing home residents' quality of life. The funds come from monetary penalties imposed against skilled nursing facilities for either the number of days or for each instance a facility is not in substantial compliance with one or more Medicare and Medicaid participation requirements for LTC Facilities (Code of Federal Regulations (CFR) 42 Part 488.430).

Because Bingocize ${ }^{\circledR}$ can facilitate strong community partnerships between educational institutions and LTC, our secondary goal of this project was to create partnerships between faculty and students at 10 universities and LTC staff. This has proven to be an important and productive partnership in three ways. First, the program provides students the opportunity to build technical knowledge, as well as relationships and empathy-building skills, which are essential to working with older adults (Yu \& Kirk, 2008). Second, the program leads to students from multiple disciplines (e.g. social work, physical therapy, psychological sciences, occupational therapy, communication sciences and disorders, gerontology, and exercise science) to acquire a deep and thorough understanding of complex issues related to aging and longterm care. Finally, Bingocize ${ }^{\circledR}$ also helps prepare students for future aging-related careers by significantly improving students' attitudes towards older adults after implementing a Bingocize ${ }^{\circledR}$ program (Neils-Strunjas et al. 2018). This is critically important considering the ongoing shortage of qualified LTC staff and high turnover rates among the LTC workforce. To understand the impact of their experiences, students complete written reflections and/or create videos highlighting their experiences. Others complete research projects that demonstrate the physical and social benefits of Bingocize ${ }^{\circ}$. The final student projects are presented to the LTC staff and residents.

Bingocize leader training is required of all participating LTC staff, university faculty, and students. The training is presented online and consists of self-paced modules taking approximately one hour to complete. Leaders learn basic exercise information including recruitment/motivational strategies, safety and training principles, and fall prevention information. They also learn techniques to communicate with residents suffering from varying degrees of dementia. Leaders can print a "Certificate of Completion" after success- 
fully completing a post-training assessment with a score of $\geq 80 \%$.

After completing training, LTC staff members schedule a Bingocize program at their respective facility and invite qualified students from the partnering university to attend the weekly sessions to aid the LTC staff. During scheduled university breaks, the LTC staff administer the program without the students.

Each LTC is provided "Bingocize" in a Box." The box includes a training manual for future reference, a leader t-shirt, prizes for game-winners, and therapy balls. Winners of Bingocize receive prizes such as lotions, paper towels, sugar-free candy, crossword puzzles, or other small personal/household items. To motivate residents to continue participating in Bingocize and create group cohesion, Bingocize $t$-shirts are available for residents.

\section{Evaluation}

The CMP project objectives are evaluated by 1 ) tracking the number of trained LTC staff and university faculty/students, 2) tracking the number of residents in attendance at each session, and 3) monitoring residents using Minimal Data Set (MDS 3.0) items that focus on fall risk, ADLs, and social engagement. After two years, over 1300 residents (mean age $79.12 \pm 9212.77$ years) with a baseline Brief Interview for Mental Status (BIMS) score of $10.22 \pm 4.47$ participated in the program; thus, indicating that LTC residents with a wide range of ages and cognitive abilities can participate in Bingocize ${ }^{\circledR}$. Additionally, 800 university students have participated. MDS 3.0 data analyses are ongoing.

\section{Comment}

The U.S. Center for Medicare and Medicaid supported this project because Bingocize provides current and future LTC residents the opportunity to participate in an innovative evidence-based program capable of improving/maintaining functional performance and increase social engagement. Applying for CMP funding either individ- ually, or in partnership with a local university, is a pragmatic way to access Bingocize and sustain the program over time. CMP funding is also available for other projects or programs capable of improving nursing home residents' quality of life.

Conflict of Interest Statement: The Western Kentucky University Research Foundation (WKURF) has a registered trademark for the term Bingocize ${ }^{\circledR}$, and author KJC and WKURF may benefit financially if WKURF is successful in marketing products related to this research. The terms of this arrangement have been reviewed and approved by Western Kentucky University in accordance with its policy on Financial Conflict of Interest in Extramural Contracts \& Grants.

\section{References}

Crandall, K. J., Fairman, C., \& Anderson, J. (2015). Functional performance in older adults after a combination multicomponent exercise program and bingo game. International Journal of Exercise Science, 8(1), 38-48.

Crandall, K. J., \& Steenbergen, K. I. (2015). Older adults' functional performance and health knowledge after a combination exercise, health education, and bingo game. Gerontology and Geriatric Medicine, 1-7. Crossref

Dipietro, L., Campbell, W. W., Buchner, D. M., Erickson, K. I., Powell, K. E., Bloodgood, B.,... VauxBjerke, A. (2019). Physical activity, injurious falls, and physical function in aging: An umbrella review. Medicine and Science in Sports and Exercise, 51(6), 1303-1313. Crossref

Dispennette, A. K., Schafer, M. A., Shake, M., Clark, B., Macy, G. B., Vanover, S., \& Crandall, K. J. (2019). Effects of a game-centered health promotion program on fall risk, health knowledge, and quality of life in community-dwelling older adults. International Journal of Exercise Science, 12(4), 1149-1160.

Falls, D., Shake, M., Norris, E., Arnett, S., Taylor, J., \& Crandall, K. J. (2018). Bingocize ${ }^{\circledR}$ : Utilizing a mobile application to improve gait in commu- 
nity-dwelling older adults. American Journal of Recreation Therapy, 17(2), 9-19. Crossref

French, M., Tade, M., Neils-Strunjas, J., Crandall, K. J., Glascock, A., McAlpin, K., \& Schaefer, S. (2016). A qualitative analysis of persons with dementia \& their experience with the game Bingocize ${ }^{\circledR}$. American Speech-Language-Hearing Association, Philadelphia, PA; November 2016.

Neils-Strunjas, J., Crandall, K. J., Shackelford, J., Dispennette, K., Stevens, L. R., \& Glascock, A. (2018). Students report more positive attitudes toward older adults following an interprofessional service-learning course. Gerontology and Geriatrics Education, 12,1-11. Crossref
Shake, M. C., Crandall, K. J., Mathews, R. P., Falls, D. G., \& Dispennette, A. K. (2018). Efficacy of Bingocize ${ }^{\circledR}$ : A game-centered mobile application to improve physical and cognitive performance in older adults. Games for Health Journal, 7(4), 253-261. Crossref

Stevens, L. (2019). Observation and self-report of fun and social engagement of nursing home residents during Bingocize (Master's thesis)، Western Kentucky University, 2019.

Yu, J. \& Kirk, M. (2008). Measurement of empathy in nursing research: Systematic review. Journal of Advanced Nursing, 64(5), 440-454. Crossref 